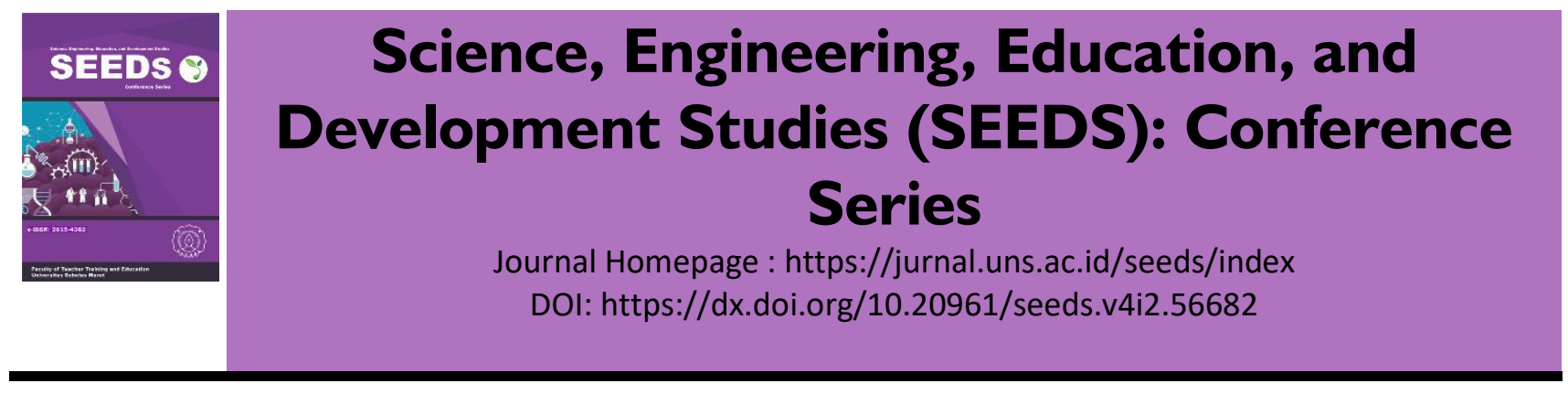

\title{
METODE PROBLEM BASED LEARNING (PBL) PADA PEMBELAJARAN SIMULASI KOMUNIKASI DIGITAL KELAS X DI SMK YOSONEGORO MAGETAN \\ Supono \\ SMK Yosonegoro Magetan \\ Arjos75@gmail.com
}

Article Info :

Available online $26 / 11 / 2021$

Keywords:

Problem based learning (PBL)

Siswa

guru

\begin{abstract}
Banyak kasus yang menunjukkan bahwa hasil belajar siswa banyak yang kurang memuaskan dan banyak nilai siswa dibawah KKM (Kriteria Ketuntasan Minimum) yang telah ditentukan, ini karena keberhasilan proses belajar mengajar terutama program pendidikan dipengaruhi oleh berbagai faktor yaitu faktor internal dan eksternal. Dari kedua factor tersebut yang utama adalah minat dan factor dari lingkungan sekitar, sehingga membuat siswa menjadi bosan, dan kelas menjadi pasif. Metode problem based learning dirasa dapat menghidupkan suasana dikelas, karena siswa dituntut dapat menyelesaikan suatu permasalahan dan guru sebagai fasilitator.
\end{abstract}




\section{PENDAHULUAN}

Kualitas pendidikan pada saat ini masih menjadi suatu masalah yang relatif menonjol dalam usaha perbaikan mutu sistem pendidikan nasional. Meskipun demikian berbagai upaya telah dilakukan untuk menguasai masalah pendidikan tersebut. Melalui pendidikan diharapkan mampu untuk mencetak generasi bangsa yang beriman dan bertakwa, berbudi luhur, cerdas, dan kreatif. Model problem based learning (PBL) merupakan salah satu model pembelajaran yang mengarahkan siswa untuk memiliki keinginan memahami, mempelajari kebutuhan pembelajaran yang baik sehingga mau menggunakan dan mencari sumber-sumber pembelajaran yang terbaik dalam rangka pemecahan masalah yang dihadapi. Nurhadi (2010) menyatakan bahwa peran guru dalam pengajaran berbasis masalah adalah menyajikan masalah, mengajukan pertanyaan, memfasilitasi penyelidikan dan dialog. Secara garis besar, problem-based learning merupakan pembelajaran yang menuntut siswa untuk belajar mandiri secara individu maupun kelompok dalam memecahkan masalah yang disajikan oleh guru. Guru berperan menyajikan masalah dan mengajukan pertanyaan yang mengarahkan siswa untuk memecahkan suatu masalah dalam kegiatan pembelajaran.

Model pembelajaran problem based learning (PBL) sebagai salah satu model pembelajaran yang akan digunakan dalam kegiatan belajar mengajar pada mata pelajaran simulasi dan komunikasi digital yang sekiranya model pembelajaran tersebut akan tepat serta efektif untuk meningkatkan kemampuan berpikir siswa dalam memecahkan suatu masalah. Maka harapan pembelajaran model Problem Based Learning adalah: (a) Dalam mata pelajaran simulasi dan komunikasi digital terdapat ranah kognitif, afektif dan psikomotor. Tujuan pembelajaran simulasi dan komunikasi digital di SMK Yosonegoro lebih mengutamakan ranah kognitif (pemahaman konsep-konsep) dan ranah psikomotor (keterampilan) disamping juga ranah afektif; (b) siswa lebih memahami dan dapat menerapkannya untuk memecahkan masalahmasalah di situasi yang berbeda; (c) Melatih siswa untuk bepikir kritis dalam penyelasaian masalah agar tidak pasif dalam menerima materi yang diberikan oleh guru; (d) Dengan metode problem based learnig diharapkan proses belajar mengajar lebih variatif dalam hal penggunaan model pembelajaran selain metode ceramah, latihan dan penugasan (konvensional) yang lazim digunakan oleh guru.

Untuk itu perlu adanya dukungan yang kuat dalam pelaksanaan sistem pendidikan agar tujuan tersebut terlaksana. Sebagai cara untuk mengatasi kebosanan, kejenuhan, dan untuk meningkatkan kemampuan belajar peserta didik pada saat proses belajar mengajar berlangsung. Dalam proses pembelajaran, unsur belajar guru memegang peranan yang penting. Inti dari kegiatan pendidikan adalah kegiatan belajar mengajar, cara siswa mengikuti kegiatan belajar-mengajar dan hasilnya akan terlihat dari hasil belajar yang diperoleh siswa.

Menurut Slutsky \& Aytac (2016), analisis bibliometrik dan khususnya kutipan telah digunakan secara luas selama beberapa dekade. Salah satu analisis bibliometrik yang digunakan untuk mempelajari kutipan, adalah dengan mempelajari daftar pustaka/artikel dari makalah yang diterbitkan. Asumsi logis dari analisis kutipan adalah bahwa artkel yang dikutip memiliki keterkaitan dengan artikel yang mengutip.

\section{PEMBAHASAN}

Model Pembelajaran Problem Based Learning Pembelajaran Berbasis Masalah (PBM) adalah model pengajaran yang bercirikan adanya permasalahan nyata sebagai konteks untuk para peserta didik belajar berpikir kritis dan ketrampilan memecahkan masalah serta memperoleh pengetahuan. PBM merupakan pengembangan kurikulum dan sistem pengajaran yang mengembangkan secara simultan strategi pemecahan masalah dan dasar-dasar pengetahuan dan ketrampilan dengan menepatkan para peserta didik dalam peran aktif sebagai pemecahan permasalahan sehari-hari yang tidak tekstruktur dengan baik-baik. Pada penelitian terdahulu model pembelajaran Problem Based Learning merupakan salah satu model pembelajaran yang inovatif yang dapat memberikan kondisi belajar aktif kepada siswa.

Metode Problem based learning mempunyai kelebihan dan kekurangan, berikut kelebihan dan kekurangan dari model pembelajaran PBL :

1. Kelebihan dari model PBL sebagai berikut :

a. Dengan PBL akan terjadi pembelajaran bermakna, peserta didik yang belajar memecahkan suatu masalah maka mereka akan menerapkan pengetahuan yang dimilikinya atau berusaha mengetahui pengetahuan yang diperlukan. 
b. Dalam situasi PBL, peserta didik mengintegrasikan pengetahuan dan ketrampilan secara simultan dan mengaplikasikannya dalam konteks yang relavan.

c. PBL dapat meningkatkan kemampuan berpikir kritis, menumbuhkan inisiatif peserta didik dan dapat mengembangkan hubungan interpersonal dlam bekerja kelompok.

2. Kekurangan model PBL sebagai berikut :

a. PBM tidak dapat ditetapkan untuk setiap materi pelajaran, ada bagian guru berperan aktif dalam menyajikan materi. PBM lebih cocok untuk pembelajaran yang menuntut kemampuan tertentu yang kaitannya dengan pemecahan masalah.

b. Dalam suatu kelas yang memiliki tingkat keragaman siswa yang tinggi akan terjadi kesulitan dalam pembagian tugas.

Langkah-langkah Model PBL (Problem Based Learning) Dalam pembelajaran PBL terdapat langkahlangkah pembelajaran yang terstruktur. Sebelum menerapkan model pembelajaran ini maka, terlebih dahulu harus memahami langkah-langkah pembelajarannya pada gambar 2.1.

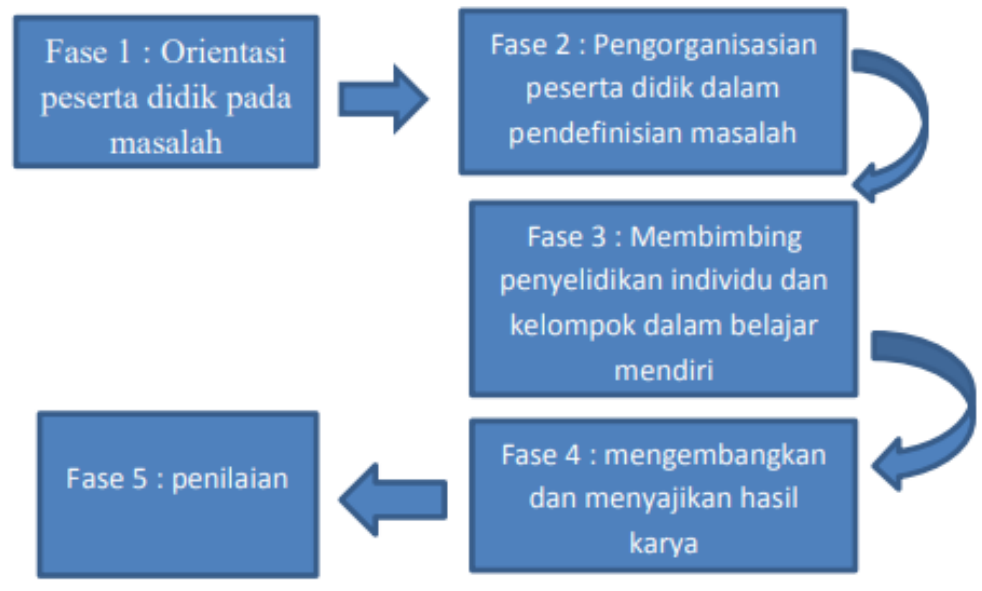

Gambar 1. Langkah model PBL (Problem Based Learning)

Langka-langkah pembelajaran Problem based learning dapat diuraikan sebagai berikut :

a. Guru menjelaskan tujuan pembelajaran, menjelaskan logistik yang dibutuhkan, memotivasi siswa terlibat dalam aktivitas pemecahan masalah yang pilih.

b. Guru membantu siswa mendefinisikan dan mengorganisasikan tugas belajar yang berhubungan dengan masalah tersebut (menetapkan topik, tugas, jadwal, dll).

c. Guru mendorong siswa untuk mengumpulkan informasi yang sesuai, eksperimen untuk mendapatkan penjelasan dan pemecahan masalah, pengumpulan data, hipotesis dan pemecahan masalah.

d. Guru membantu siswa dalam merencanakan serta menyiapkan karya yang sesuai seperti laporan dan membantu mereka berbagai tugas dengan temannya.

e. Guru membantu siswa untuk melakukan refleksi atau evaluasi terhadap penyelidikan mereka dan proses-proses yang mereka gunakan

Bedasarkan teori yang dikembangkan Barrow, Min Liu, karakteristik dari PBM / PBL sebagia berikut :

a. Learning is student-centered Proses pembelajaran dalam PBL lebih menitik beratkan kepada siswa sebagai orang belajar. Oleh karena itu, PBL didukung juga oleh teori konstruktivisme dimana siswa didorong untuk dapat mengembangkan pengetahuannya sendiri.

b. Authentic problems form the organizing focus for learning. Masalah yang disajikan kepada siswa adalah masalah yang otentik sehingga siswa mampu dengan mudah memahami masalah tersebut serta dapat menerapkannya dalam kehidupan profesionalnya nanti.

c. New information is acquired thruogh self-directed learning. Dalam proses pemecahan masalah mungkin saja siswa belum mengetahui dan memahami semua pengetahuan prasyaratnya sehingga siswa berusaha untuk mencari sendiri melalui sumbernya, baik dari buku atau informasi lainnya.

d. Learning occurs in small groups. Agar terjadi interaksi ilmiah dan tukar pemikiran dalam usahaa membangun pengetahuan secara kolaboratif, PBM dilaksanakan dalam kelompok kecil. Kelompok yang dibuat menuntut pembagian tugas yang jelas dan penetapan tujuan yang jelas.

e. Teachers act as facilitators. Pada pelaksanaan PBM, guru hanya berperan sebagai fasilitator. Meskipun begitu guru harus selalu mematau perkembangan aktivitas siswa dan mendorong mereka agar mencapai target yang hendak dicapai. 
Tujuan Model PBL (Problem Based Learning) dan hasil dari model pembelajaran berbasis masalah atau Problem Based Learning sebagai berikut :

a. Keterampilan berpikir dan ketrampilan memecahkan masalah.

b. Pembelajaran berbasis masalah ini diwujudkan untuk mengembangkan ketrampilan berpikir tingkat tinggi.

c. Pemodelan peranan orang dewasa.

d. Bentuk pembelajaran berbasis masalah penting menjembatani antara pembelajaran sekolah formal dengan aktivitas mental yang lebih praktis yang dijumpai diluar sekolah.

e. PBL mendorong kerjasama dalam menyelesaikan tugas.

f. PBL memiliki elemen-elemen magang. Hal ini mendorong pengamatan dan dialog dengan yang lain.

g. PBL melibatkan peserta didik dalam penyelidikan pilihan sendiri, yang memungkinkan mereka menginterasikan dan menjelaskan fenomena dunia nyata.

h. Belajar pengarahan sendiri (self directed learning).

i. Pembelajran berbasis masalah berpusat pada peserta didik, peserta didik harus dapat menentukan sendiri apa yang harus dipelajari dan dari mana informasi harus di peroleh, dibawah bimbingan guru

\section{KESIMPULAN}

Pembelajaran menggunakan metode problem based learning lebih efektif dan dapat menghidupkan suasana kelas. Karena belajar lebih menyenangkan dan siswa lebih aktif. Guru sebagai fasilitator dapat memantau siswa lebih mudah.

\section{DAFTAR PUSTAKA}

Santoso, Danar; Ristu, Fatia Syufia. Pengaruh Pembelajaran Problem Based Learning (Pbl) Terhadap Hasil Belajar Siswa Pada Mata Pelajaran (Simdig) Di Kelas X SMK Bina Dharma Pontianak. In: Prosiding Seminar Nasional Pendidikan Mipa Dan Teknologi II. 2019. P. 134-142.

Mauliza, Cut Naula, et al. Pengaruh Model Pembelajaran Problem Based Learning (PBL) Terhadap Hasil Belajar Siswa Kelas X pada Mata Pelajaran Simulasi dan Komunikasi Digital Di SMK Darul Ihsan. 2019. PhD Thesis. UIN Ar-Raniry Banda Aceh.

Irawadi, I. Komang. Pengembangan Media Pembelajaran Interaktif Berbasis Masalah Untuk Meningkatkan Prestasi Belajar Siswa Pada Mata Pelajaran Simulasi Dan Komunikasi Digital DI SMK TI Bali Global Singaraja. 2019. $\mathrm{PhD}$ Thesis. Universitas Pendidikan Ganesha.

Rahmat, Riki Fajri, Dkk. Pengembangan Media Pembelajaran Berbasis Mobile Learning Pada Mata Pelajaran Simulasi Digital. Jurnal Inovasi Teknologi Pendidikan, 2019, 6.2: 116-126.

Lelasari, Maharani; Setyosari, Punaji; Ulfa, Saida. Networked Learning Dengan Strategi Problem Solving Pada Mata Pelajaran Simulasi Digital. JINOTEP (Jurnal Inovasi dan Teknologi Pembelajaran): Kajian dan Riset Dalam Teknologi Pembelajaran, 2019, 5.1: 15-23.

Muhajir, Muhajir; Musfikar, Rahmat; Hazrullah, Hazrullah. Efektivitas Penggunaan E-Learning Berbasis Edmodo Terhadap Minat Dan Hasil Belajar (Studi Kasus Di SMK Negeri AL Mubarkeya). Cyberspace: Jurnal Pendidikan Teknologi Informasi, 2019, 3.1: 50-56.

Suarbawa, I. Putu. Penerapan Model Problem Based Learning (Pbl) Pada Mata Pembelajaran Corel Draw Untuk Meningkatkan Hasil Belajar Di Ranah Psikomotor. Indonesian Journal Of Educational Research and Review, 2019, 2.2: $162-171$.

Nurilahi, Desi Kurnia, Et Al. Efektivitas Model Pembelajaran Problem Based Learning Dalam Pencapaian Kompetensi Teknologi Jaringan Berbasis Luas (WAN) Menggunakan Software GNS3 (Studi Kasus Siswa Kelas XI (TKJ) SMKN 2 Banda Aceh). 2019. PhD Thesis. UIN Ar-Raniry Banda Aceh.

Malika El Istiqamafaruq, Sayyida; Sujalwo, M. Pengembangan Media Pembelajaran Modul Digital Interaktif Metode Problem Based Learning Guna Memberdayakan Kemampuan Berfikir Kritis Siswa Pada Mata Pelajaran Simulasi Dan Komunikasi Digital Kelas X . 2019. Skripsi. Universitas Muhammadiyah Surakarta.

Barangan, Yonis. Pengembangan Modul Cetak Pada Mata Pelajaran Simulasi Digitalmateri Komunikasi Dalam Jaringan (Daring Online) Untuk Siswa Kelas Xsmk Siti Aminah Surabaya. Jurnal Mahasiswa Teknologi Pendidikan, 2018, 9.2.

Rahmayu, Mulia; Purnomo, Catur Eko; Sudrajat, Budi. Aplikasi Ujian Online Berbasis Intranet Pada Mata Pelajaran Simulasi Digital Di SMK Yadika 4 Ciledug. Petir: Jurnal Pengkajian dan Penerapan Teknik Informatika, 2019, 12.2: 145-154. 
KURNIAWAN, Randi Surya. Penerapan model pembelajaran problem based learning untuk meningkatkan prestasi belajar siswa kelas X pada mata pelajaran simulasi digital di SMK Negeri 1 Udanawu Blitar. 2018. PhD Thesis. Universitas Negeri Malang.

WABDILLAH, Wabdillah. Implementasi metode problem based learning pada mata pelajaran simulasi digital di SMK Darussalam Makassar. Inspiration: Jurnal Teknologi Informasi dan Komunikasi, 2016, 6.1.

SANTOSA, Alif Satria Egar, et al. Pengembangan e-modul berbasis model pembelajaran problem based learning pada mata pelajaran administrasi jaringan kelas XII teknik komputer dan jaringan di SMK TI Bali global Singaraja. KARMAPATI (Kumpulan Artikel Mahasiswa Pendidikan Teknik Informatika), 2017, 6.1: 62-72. 